ISBN 978-81-933894-1-6

International Conference on Arts, Social Sciences, History and Interdisciplinary Studies

(ASSHIS-2017)

Kyoto (Japan) April 20-21, 2017

\title{
Factors of Personnel Performance Motivation at Minburi Home Mart Co. Ltd., Minburi District
}

\author{
Manop. Kongsak MBA, Tosaporn mahamud Ph.D \\ Kasembundit University,Bangkok \\ tosaporn.mah@kbu.ac.th
}

\begin{abstract}
The purpose of this study were to determine factors of personnel performance motivation and job satisfaction at Minburi Home Mart Co., Ltd., Minburi District by using quantitative research for data analysis which consisted of independent variables such as gender, age, level of education, work experiences, and their income. Statistics application for data analysis were percentage, mean, standard deviation, and regression.

Findings from the study indicated that most of respondents were females, age between 21-30 years old, earned vocational certificate education, and average income between 8,000-15,000 baht. Factors of personal different such as gender, age, level of education, occupation, and monthly income correlated in statistical significant at 0.05 level. The average picture of the opinions of factors of performance motivation affected job satisfaction of the personnel was at high level.
\end{abstract}

Keyword: Personnel Performance Motivation

\section{Introduction}

Home Mart Min Buri Company Limited has been established company. The construction materials on 15 November 2556 by the business in the Trading Street Umbrella Lounge Area later expanded its distribution center in the nearby area of over 10 hectares to accommodate the needs of customers increases. up And with the demand for building materials continued to rise every year. The company began transitioning into becoming a distributor of building materials major. Because earlier in the year. Fri . 2522 incorporated Buri Lumber Co. doing business with the sale of lumber, plywood, lumber and business long before it opened. Min Buri Home Mart The two companies are located nearby. The same owner

The work of this company will be sales AE (Sales Executive), acting as a salesperson is responsible for sales quotations issued by the task that has been assigned. Customer care and after sales support PE (Product Expensive) serves to introduce the product to the knowledge of the product. Resolve customer issues Consulting on building materials such as SO (Sales Order) act out the sales document to discount prices to reduce debt, make return reservations, transportation, payment and collection of the sales document. All parties will work together. The division of the department, but work out.

The AE acts to do a quotation to the customer to close a sale, when closing the sale, will be sent to SO bill receipt, payment, and face. PE waiting for delivery to customers, which may be a problem with Factors in the work of the staff and the performance and potential dispute in the enterprise, it is to study the factors affecting the performance of the company. Min Buri home mart SCG Dealer minburi area. It will get to know about feeling factors in the work of employees, but the person that have feeling? 
Opinions on the organization? You know the problem And to improve that point. So that employees are encouraged to do the work and organization have evolved and progressed to the company. Min Buri Home Mart A retail subsidiary of The Siam Cement Public Company Limited, the operator of the administration, " the SCG the Home Solution Translate" source of goods and materials for decoration, repair housing solutions. Materials include the full range of the latest large-format Thailand. To expand the audience away. Originally made goods for home alone. We have a target to reach homeowners. Federal contractors and retail projects, owners, retailers and homeowners looking to source materials for the construction of facilities. The lowest prices every day With its modern and versatile Products are sufficient to meet demand. Quick and easy Customers who use the service can be received immediately. It also offers credit card. Loans and various other things " the SCG the Home Solution Translate" a large area inside the building. Equipped with quality products at a variety of leading brands, more than 5,000 items, including the structure and tools, including brick, stone, cement, asphalt, steel, galvanized sheet piling, roofing, gypsum, insulation, wood and plywood siding, including tools and. all kinds of hardware The decoration of the architecture include doors, windows, screen doors, railing, wood, wood cornice tile flooring, wall colors and related parts etc. in the electrical system, such as a lamp in a house outside of the home fans, ceiling lamp cord set, socket switch. Switch breaker group plumbing - sanitation such as water pipes, faucets, valves, water pumps. water filter Water heater Underground storage tanks, water pipes, fittings and accessories. Including equipment And tools related to agriculture Etc. There is also a Browse and stay home. With all appliances. To store supplies such as curtains, blinds shading devices, appliances, bathroom, kitchen, sleeping room, all of which have been brought together. Complete with a vast product Several categories including more than 5,000 items, including structures and foundations, including brick, stone, cement, sand, steel sheet piling, ground to roof, decorative home accessories, furniture and electrical goods, we insist on policy. In everyday low prices Clients do not have to wait for the event. Promotional Or discount store To stress that Watsadu It is the leading product Construction materials The price of good quality Thailand A warranty And can change Return on The only source you can get everything you want at a cheap price and quality

\section{The purpose of the Study and Research Methods}

To study the motivation that affected the performance of employees, min Buri Buri, home mart area And to study the satisfaction level of employees, min Buri home mart area area population study has 120 people. And want to error in sampling and 5 sample size should be how much.

$$
\begin{aligned}
\text { The sample size is calculated. } \mathrm{n}= & \mathrm{N} \\
= & \frac{1+\mathrm{Ne}^{2}}{120}=\begin{array}{r}
92 \\
1+120(.05)^{2}
\end{array}
\end{aligned}
$$

The sample must be selected 92 คน

\section{The Results of the Study}

The study of work motivation of employees, min Buri Buri, home mart area The study used as follows: the discussion of work motivation Respondents most needs more income, welfare and the สิทธิการ la. A division of the work and responsibilities clear. A supervisor or executive to supervise employees. Wait for advice and solve problems have individual sense of work, such as a position, etc..

No incentives to workers or valuable in terms of people motivation factors involved but it is satisfy to individuals working or protection prevent dissatisfaction in contribution to work more comfy is regarded as only one measure to meet the needs of other things. What will cause the motivation for a person to work if the environment has provided a good enough just as the needs of the work. 


\section{Suggestions for Further Study}

The objective of this study is to factor in performance, so in the next study should job motivation in various fields. For the details).

\begin{tabular}{|c|c|c|c|c|c|c|}
\hline $\begin{array}{l}\text { Factors that affect the } \\
\text { motivation of practitioners }\end{array}$ & B & $\begin{array}{l}\text { Std. } \\
\text { Error }\end{array}$ & Beta & $\mathrm{t}$ & Sig. & Test results \\
\hline (Constant) & 3.551 & .820 & & 4.329 & .000 & relation \\
\hline $\begin{array}{l}\text { The road marker corresponds } \\
\text { to the knowledge and ability } \\
\text { of the person. }\end{array}$ & 3.857 & 2.538 & 4.470 & 1.520 & .136 & No relation \\
\hline $\begin{array}{l}\text { Job is responsible meet the } \\
\text { job description. }\end{array}$ & -.236 & .196 & -.261 & -1.205 & .235 & No relation \\
\hline $\begin{array}{l}\text { Job responsibilities are } \\
\text { important and interesting }\end{array}$ & -.338 & .559 & -.400 & -.605 & .549 & No relation \\
\hline $\begin{array}{l}\text { The responsibility to get the } \\
\text { work load is appropriate. }\end{array}$ & .320 & .287 & .369 & 1.113 & .272 & No relation \\
\hline $\begin{array}{l}\text { Decide on your assignments } \\
\text { by yourself. }\end{array}$ & -.014 & .217 & -.017 & -.063 & .950 & No relation \\
\hline $\begin{array}{l}\text { Having defined the } \\
\text { responsibilities clearly to be } \\
\text { able to perform }\end{array}$ & -.047 & .177 & -.058 & -.267 & .791 & No relation \\
\hline $\begin{array}{l}\text { Can improve your position, } \\
\text { you have a chance to } \\
\text { progress. }\end{array}$ & -.026 & .151 & -.030 & -.173 & .864 & No relation \\
\hline $\begin{array}{l}\text { the opportunity to be trained } \\
\text { in order to increase the } \\
\text { knowledge, skills, work their } \\
\text { own }\end{array}$ & -.263 & .296 & -.302 & -.887 & .380 & No relation \\
\hline $\begin{array}{l}\text { the opportunity to be } \\
\text { promoted according to } \\
\text { ability. }\end{array}$ & .783 & .517 & .878 & 1.516 & .137 & No relation \\
\hline $\begin{array}{l}\text { Guests receive accolades } \\
\text { from bosses. }\end{array}$ & -.056 & .546 & -.064 & -.103 & .919 & No relation \\
\hline $\begin{array}{l}\text { You get compliments from } \\
\text { colleagues. }\end{array}$ & .016 & .450 & .018 & .035 & .972 & No relation \\
\hline $\begin{array}{l}\text { Your opinion is accepted by } \\
\text { their superiors. }\end{array}$ & -.770 & .453 & -.872 & -1.698 & .097 & No relation \\
\hline $\begin{array}{l}\text { Your opinion is accepted of } \\
\text { colleagues. }\end{array}$ & -.678 & .818 & -.760 & -.830 & .411 & No relation \\
\hline $\begin{array}{l}\text { When you have problems } \\
\text { that you can solve the } \\
\text { problem itself }\end{array}$ & .002 & .437 & .002 & .004 & .997 & No relation \\
\hline
\end{tabular}




\begin{tabular}{|c|c|c|c|c|c|c|}
\hline $\begin{array}{l}\text { work in line with the goals } \\
\text { of the organization. }\end{array}$ & -.734 & .357 & -.821 & -2.056 & .046 & relation \\
\hline deliver the project on time & -.237 & .149 & -.270 & -1.595 & .118 & No relation \\
\hline $\begin{array}{l}\text { The functions of the } \\
\text { organization but was clearly } \\
\text { and correctly. }\end{array}$ & .321 & .416 & .372 & .773 & .444 & No relation \\
\hline $\begin{array}{l}\text { Organizational policies, } \\
\text { practices and, of course, } \\
\text { obvious. }\end{array}$ & -1.227 & .495 & -1.406 & -2.479 & .017 & relation \\
\hline $\begin{array}{l}\text { There are rules to assign } \\
\text { tasks to perform, but people } \\
\text { with knowledge and in line } \\
\text { with the }\end{array}$ & -.666 & .601 & -.755 & -1.107 & .274 & No relation \\
\hline $\begin{array}{l}\text { There are rules and } \\
\text { regulations in writing }\end{array}$ & .190 & .922 & .216 & .206 & .838 & No relation \\
\hline $\begin{array}{l}\text { Do you think bosses are } \\
\text { knowledgeable in the } \\
\text { management of the car. }\end{array}$ & -.199 & .318 & -.232 & -.624 & .536 & No relation \\
\hline $\begin{array}{l}\text { The bosses there is justice in } \\
\text { administration }\end{array}$ & -.178 & .574 & -.225 & -.310 & .758 & No relation \\
\hline $\begin{array}{l}\text { Willing to teach their } \\
\text { superiors on subordinates. }\end{array}$ & .208 & .467 & .248 & .444 & .659 & No relation \\
\hline $\begin{array}{l}\text { Satisfied about the income } \\
\text { that you receive. }\end{array}$ & .054 & .476 & .059 & .112 & .911 & No relation \\
\hline $\begin{array}{l}\text { Satisfied about the bonus } \\
\text { you receive. }\end{array}$ & -.406 & .724 & -.444 & -.561 & .577 & No relation \\
\hline $\begin{array}{l}\text { satisfied about the overtime } \\
\text { you have received. }\end{array}$ & .850 & .641 & .942 & 1.327 & .191 & No relation \\
\hline $\begin{array}{l}\text { satisfied about the rights to } \\
\text { pick up medical treatment } \\
\text { you have received. }\end{array}$ & .383 & .438 & .444 & .875 & .386 & No relation \\
\hline $\begin{array}{l}\text { satisfied about the various } \\
\text { rights to La. }\end{array}$ & .239 & .475 & .288 & .503 & .617 & No relation \\
\hline $\begin{array}{l}\text { You get a chance to keep } \\
\text { practicing and working on } \\
\text { their own time. }\end{array}$ & .073 & .440 & .086 & .166 & .869 & No relation \\
\hline $\begin{array}{l}\text { Commanding your support in } \\
\text { advance whenever possible. }\end{array}$ & -.113 & .362 & -.131 & -.313 & .755 & No relation \\
\hline $\begin{array}{l}\text { To get a chance to know. } \\
\text { Capacity and skills In the } \\
\text { check operation }\end{array}$ & .350 & .395 & .400 & .886 & .381 & No relation \\
\hline
\end{tabular}




\begin{tabular}{|c|c|c|c|c|c|c|}
\hline Building work site is safe. & -.064 & .345 & -.075 & -.186 & .854 & No relation \\
\hline $\begin{array}{l}\text { Equipped with facilities that } \\
\text { are used to working with } \\
\text { modernization. }\end{array}$ & -.072 & .370 & -.083 & -.195 & .847 & No relation \\
\hline $\begin{array}{l}\text { Workplace lighting suitable } \\
\text { for the operation. }\end{array}$ & .195 & .273 & .231 & .712 & .480 & No relation \\
\hline $\begin{array}{l}\text { Operating environment at } \\
\text { appropriate temperature }\end{array}$ & .576 & .318 & .664 & 1.809 & .077 & No relation \\
\hline $\begin{array}{l}\text { The rooms have been } \\
\text { accounted for work. }\end{array}$ & .368 & .363 & .419 & 1.014 & .316 & No relation \\
\hline $\begin{array}{l}\text { Attitude towards } \\
\text { subordinates. }\end{array}$ & .193 & .291 & .238 & .661 & .512 & No relation \\
\hline To continue the subordinates & -.367 & .266 & -.456 & -1.380 & .175 & No relation \\
\hline $\begin{array}{l}\text { To discuss and make } \\
\text { recommendations at any } \\
\text { time. }\end{array}$ & -.054 & .305 & -.065 & -.175 & .861 & No relation \\
\hline Attitude towards colleagues. & .251 & .667 & .271 & .377 & .708 & No relation \\
\hline $\begin{array}{l}\text { Operating together, cause } \\
\text { good relationship between } \\
\text { colleagues. }\end{array}$ & .039 & .654 & .042 & .059 & .953 & No relation \\
\hline $\begin{array}{l}\text { The agency has a team made } \\
\text { good relationships with each } \\
\text { other. }\end{array}$ & -1.067 & .442 & -1.152 & -2.417 & .020 & relation \\
\hline Colleagues honor together. & -.572 & .679 & -.633 & -.841 & .405 & No relation \\
\hline Matric good bosses. & -.292 & .422 & -.322 & -.690 & .494 & No relation \\
\hline $\begin{array}{l}\text { The consult with supervisors } \\
\text { at any time }\end{array}$ & -.089 & .473 & -.098 & -.187 & .852 & No relation \\
\hline $\begin{array}{l}\text { Resolve the matter in } \\
\text { conjunction with the bosses. }\end{array}$ & -.621 & .405 & -.686 & -1.534 & .132 & No relation \\
\hline $\begin{array}{l}\text { consult with a personal } \\
\text { supervisor }\end{array}$ & -.088 & .397 & -.096 & -.222 & .825 & No relation \\
\hline
\end{tabular}

Compare the relationship motivation affects the bond per organization

Compare the relationship motivation affect organizational commitment of the employees. Min Buri Home Mart And that is no different from the assumption that all aspects of motivation is no different, except for policy administration. And a private address The different levels of significance. 05 In conclusion, the motivation of each of the above is very different so it does not change the company's employees. Min Buri Home Mart, but for an organizational commitment to the policy of the administration and the well-being of employees has resulted. Min Buri Home Mart The resulting organizational commitment 


\section{References}

[1] Sang Charoen please: 2006 Factors that affect the operation of the cable manufacturing company employee $\mathrm{n}$ o $\mathrm{k}$ precision. Components (Thailand) co., Ltd.

[2] NIPA House Mon Ta: 2013 Factors that affect the performance of the employee, Bank of Thailand public company limited (Thai) in Lampang.

[3] Pattama PON phet treasure: 2008 Factors that affect the performance of the employee, Bangkok life assurance plc.

[4] Pichet Phu Chung as nahathaen luck: 2005 as factors that affect the performance of the tanning factory employees. 